\title{
Research on Intellectual Property Protection in Colleges and Universities*
}

\author{
Jipeng Wei \\ Shanghai Ocean University \\ Shanghai, China 201306
}

\author{
Weijiang Wang** \\ Shanghai Ocean University \\ Shanghai, China 201306 \\ **Corresponding Author
}

\begin{abstract}
Colleges and universities, as the source of achievements, innovation and dissemination of knowledge and the cradle of personnel training, have contributed a lot of knowledge and scientific and technological achievements to the whole country and society. To integrate with the intellectual property system and to protect scientific and technological achievements has become a new topic for science and technology administrators in the period of entering the integration of the scientific and technological achievement management system and the intellectual property system, especially since the issuance of the national intellectual property strategy outline and the construction of an innovative country. Based on the theory of intellectual property rights, this paper takes Shanghai Ocean University as an example, and analyzes the practical problems in the protection of intellectual property rights of some characteristic universities and colleges in Shanghai. The author wants to explore the corresponding measures and management methods for the relevant departments and colleges and universities.
\end{abstract}

Keywords-intellectual property; protection; characteristic; universities; research

\section{INTRODUCTION}

With the rapid development of intellectual property, the society pays more and more attention to the intellectual property. The understanding is deep. With the issuance of the national intellectual property strategy outline and the construction of the innovative country, the protection of intellectual property has been raised to a new height. Colleges and universities, as pioneers in scientific and technological innovation, have produced a lot of knowledge and scientific and technological results. However, there are always problems in the protection of intellectual property in colleges and universities. To integrate with the developing intellectual property system and to protect scientific and technological achievements need to be studied and considered. Although many scholars have studied the intellectual property of colleges and universities and put forward a lot of suggestions and measures, the protection of intellectual property of colleges and universities is limited. And its operability is not strong. Based on the theory and practice, this paper analyzes the practical problems in the

*Fund Project: Funded by the Science and Technology Development Fund of Shanghai Ocean University. Project Number: A2-0203-17100218 protection of intellectual property in characteristic universities and colleges in Shanghai, and puts forward some suggestions on the cultivation of intellectual property awareness, propaganda, organizational system and system construction, and the transformation of scientific and technological achievements.

\section{INTELLECTUAL PROPERTY}

\section{A. Concepts}

Intellectual property refers to the rights enjoyed by people in accordance with the law to the achievements created by their intellectual activities and to the marks and credibility of their business management activities [1]. At present, it refers to the copyright and its neighboring right, patent right, trademark right, service mark right, source mark right, origin name right and so on, as well as a kind of general title to prevent unfair competition right.

\section{B. Scope}

In a broad sense, intellectual property is defined by "Convention of the World Intellectual Property Organization". And it is signed in Stockholm on 14 July 1967. It includes the following items:

- Rights relating to literary, artistic and scientific works. This is commonly referred to copyright.

- Rights relating to performances, sound recordings and broadcasts by performing artists. This mainly refers to the so-called neighboring rights.

- Rights relating to inventions in all ways of human creative activity. This mainly refers to the rights enjoyed by patented inventions, utility model patents and non-patented inventions.

- Rights relating to scientific discoveries.

- Rights relating to industrial designs.

- Rights relating to merchandise trademarks, service trademarks, trademarks and other marks.

- Rights relating to the prevention of unfair competition. 
- All other rights arising from intellectual creative activities in the fields of industry, science, literature and art.

The General Principles of Civil Law of China affirm that intellectual property is an independent civil right. Section 3 of Chapter 5 of the General Principles of Civil Law specifies intellectual property rights, which stipulates six types of intellectual property rights, namely copyright, patent right, trademark right, discovery right, invention right and other scientific and technological achievements right.

At present, the intellectual property rights are mainly patent right, right of proprietary technology, trademark right and copyright.

\section{Formation of Intellectual Property System in China}

The construction of intellectual property system in China is relatively late. However, it develops rapidly. The formation of intellectual property system can be divided into three periods:

First, it is from the founding of the People's Republic of China to the convening of the Third Plenary Session of the Eleventh Central Committee in 1978. It is mainly to regulate, adjust and safeguard through the party and state policies.

Second, it is from the Third Plenary Session of the Eleventh Central Committee of the Communist Party of China in 1978 to the second session of the Ninth National People's Congress in 1999. During this period, China promulgated and implemented a series of laws. The legal framework of intellectual property with patent, trademark and copyright as the three pillars has been basically formed in China, which makes the legal system of intellectual property basically complete. At the same time of establishing and perfecting the domestic intellectual property legislation system, China undertakes the international obligation of protecting intellectual property actively. In 1980, China joined the World Intellectual Property Organization. And then, it had joined a series of conventions, agreements and treaties. For example, in 1985, it became a member of Paris Convention for the Protection of Industrial Property. In 1989, it became the 27th member of Madrid Agreement on International Registration of Trademarks. In 1992, it became a member of Berne Convention for the Protection of Literary and Artistic Works and the Agreement on Trade-Related Aspects of Intellectual Property Rights (Trips).

The third is from the second session of the Ninth National People's Congress in 1999 to the present. China gradually adjusted its legal framework and properly docked with the WTO.

\section{THE STATUS QUO AND PROBLEMS OF INTELLECTUAL PROPERTY DEVELOPMENT IN UNIVERSITIES}

\section{A. The Model of Intellectual Property Management in Universities}

In recent years, the State Council and the Ministry of Education have successively issued a series of documents such as the "Outline of the National Intellectual Property Strategy" and the "Regulations on the Administration of Intellectual Property Protection in Colleges and Universities" to regulate the management and protection of intellectual property in universities [1]. Universities also carried out corresponding management of intellectual property rights. At present, the Science and Technology Department is the main department that manages intellectual property rights in most colleges and universities. The management of intellectual property rights in various institutions of higher learning basically belongs to several departments such as the Science and Technology Department and the Science and Technology Industry Office. The intellectual property management in universities is mainly based on patent management. In terms of patent management, colleges and universities have different management models because of their different nature, foundation, and different requirements. There are three main types: centralized management and two-stage decentralized management and three-stage decentralized management.

According to analyzing 11 local universities in Shanghai (seeing "Table I"), the current management model for intellectual property rights in local universities in Shanghai is mainly centralized management ( 5 in total). The followed one is two-stage decentralized management (4 universities). The three-stage decentralized management is the least (two universities). From the side, we can see the current development of the intellectual property management model in Chinese universities.

At present, the intellectual property management system in universities is still under exploration. Various management models have their own advantages and disadvantages. With the continuous improvement and development of intellectual property in institutions, the intellectual property management system in universities will also become more and more mature. Through the cooperation and exchange, we can find out a certain management model that is suitable for the characteristics of the university and adapts to the social environment. It would better promote the development of the university. 


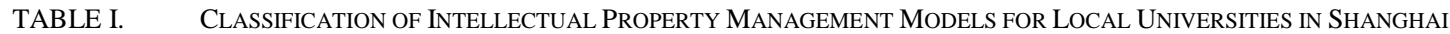

\begin{tabular}{|c|c|c|c|}
\hline $\begin{array}{c}\text { Serial } \\
\text { Number }\end{array}$ & $\begin{array}{l}\text { Intellectual Property } \\
\text { Management Models }\end{array}$ & Universities & Specific Management \\
\hline 1 & \multirow{2}{*}{$\begin{array}{l}\text { Three-stage } \\
\text { Decentralized } \\
\text { Management }\end{array}$} & $\begin{array}{l}\text { Shanghai University of } \\
\text { Traditional Chinese } \\
\text { Medicine }\end{array}$ & $\begin{array}{l}\text { Intellectual Property Research Center — Intellectual Property Protection } \\
\text { and Evaluation, etc. } \\
\text { Science and Technology Department — Intellectual Property Application } \\
\text { Statistics, etc. } \\
\text { Technology Transfer Center (Industry, Research, and Research Office) - } \\
\text { Conversion of Intellectual Property }\end{array}$ \\
\hline 2 & & Shanghai University & $\begin{array}{l}\text { Intellectual Property Academy - Intellectual Property Protection and } \\
\text { Evaluation, etc. } \\
\text { Science and Technology Department - Intellectual Property Application } \\
\text { Statistics, etc. } \\
\text { Technology Transfer Center (science and technology field in university) } \\
\text { - Conversion of Intellectual Property }\end{array}$ \\
\hline 3 & \multirow{4}{*}{$\begin{array}{l}\text { Two-stage Decentralized } \\
\text { Management }\end{array}$} & $\begin{array}{l}\text { Shanghai } \\
\text { University }\end{array}$ & $\begin{array}{l}\text { Science and Technology Department }- \text { Statistics, Protection and } \\
\text { Evaluation of Intellectual Property Applications, etc. } \\
\text { Technology Transfer Center (Asset Management Company) - } \\
\text { Conversion of Intellectual Property }\end{array}$ \\
\hline 4 & & $\begin{array}{l}\text { Shanghai Ocean } \\
\text { University }\end{array}$ & $\begin{array}{l}\text { Science and Technology Department }- \text { Statistics, Protection and } \\
\text { Evaluation of Intellectual Property Applications, etc. } \\
\text { Technology Transfer Center (Asset Management Company) - } \\
\text { Conversion of Intellectual Property }\end{array}$ \\
\hline 5 & & $\begin{array}{l}\text { Shanghai Institute of } \\
\text { Technology }\end{array}$ & $\begin{array}{l}\text { Science and Technology Department }- \text { Statistics, Protection and } \\
\text { Evaluation of Intellectual Property Applications, etc. } \\
\text { Technology Transfer Center (Asset Management Company) - } \\
\text { Conversion of Intellectual Property }\end{array}$ \\
\hline 6 & & $\begin{array}{l}\text { Shanghai Second } \\
\text { Polytechnic University }\end{array}$ & $\begin{array}{l}\text { Science and Technology Department - Statistics, Protection and } \\
\text { Evaluation of Intellectual Property Applications, etc. } \\
\text { Technology Transfer Center (Independent) - Conversion of Intellectual } \\
\text { Property }\end{array}$ \\
\hline 7 & \multirow{5}{*}{ Centralized Management } & $\begin{array}{l}\text { Shanghai } \\
\text { University }\end{array}$ & $\begin{array}{l}\text { Unified management of Science and Technology Department } \\
\text { (Technology Transfer Center belongs to Management of Science and } \\
\text { Technology Department) - Statistics, Protection and Evaluation and } \\
\text { Achievement Transformation of Intellectual Property }\end{array}$ \\
\hline 8 & & $\begin{array}{l}\text { Shanghai University Of } \\
\text { Engineering Science }\end{array}$ & $\begin{array}{l}\text { Unified management of Science and Technology Department } \\
\text { (Technology Transfer Center belongs to Management of Science and } \\
\text { Technology Department) - Statistics, Protection and Evaluation and } \\
\text { Achievement Transformation of Intellectual Property }\end{array}$ \\
\hline 9 & & $\begin{array}{l}\text { University of Shanghai } \\
\text { for Science and } \\
\text { Technology }\end{array}$ & $\begin{array}{l}\text { Unified management of Science and Technology Department } \\
\text { (Technology Transfer Center belongs to Management of Science and } \\
\text { Technology Department) - Statistics, Protection and Evaluation and } \\
\text { Achievement Transformation of Intellectual Property }\end{array}$ \\
\hline 10 & & $\begin{array}{l}\text { Shanghai University Of } \\
\text { Electric Power }\end{array}$ & $\begin{array}{l}\text { Unified management of Science and Technology Department } \\
\text { (Technology Transfer Center belongs to Management of Science and } \\
\text { Technology Department) - Statistics, Protection and Evaluation and } \\
\text { Achievement Transformation of Intellectual Property }\end{array}$ \\
\hline 11 & & $\begin{array}{l}\text { Shanghai } \\
\text { University }\end{array}$ & $\begin{array}{l}\text { Unified management of Science and Technology Department } \\
\text { (Technology Transfer Center belongs to Management of Science and } \\
\text { Technology Department) - Statistics, Protection and Evaluation and } \\
\text { Achievement Transformation of Intellectual Property }\end{array}$ \\
\hline
\end{tabular}

\section{B. The Role of Intellectual Property Management of University}

Universities and colleges are places where scientific research talents are concentrated. The scientific research is strong. And professional coverage is wide. It is the major sources of knowledge innovation, important birthplaces and radiation sources of intellectual property. Scientific research and innovation in colleges and universities can radiate the development of science and technology and technological advancement in the surrounding areas. And it can promote the development of the local economy. The birth and development of science and technology industrial areas such as Silicon Valley in the United States and Zhongguancun in Beijing are inseparable from colleges and universities [2]. The intellectual property management in colleges and universities is to implement intellectual property law and national intellectual property strategy. Through the management of all major aspects of intellectual property in colleges and universities, the overall improvement of the quality of intellectual property in colleges and universities has a positive impact on the scientific and technological work in colleges and universities. At the same time, the implementation of intellectual property system can also bring 
significant social and economic benefits to colleges and universities. Therefore, the management of intellectual property rights in universities is not limited to the management and protection of existing intellectual property rights. It is also of great significance to the advancement of universities and the advancement of industrialization of science and technology.

\section{The Situation of Intellectual Property over the Years}

The development of intellectual property in colleges and universities is rapid. Especially, it has great increase in patents, software copyrights and other aspects. Taking patent as an example, in 2016, the number of Shanghai patent applications was 119,937. And the number of granted patents was 64,230, of which 10595 applications had been publicly announced by universities and colleges. And the number of authorizations was about 6,000 , all surpassing the level of 2015 [3].

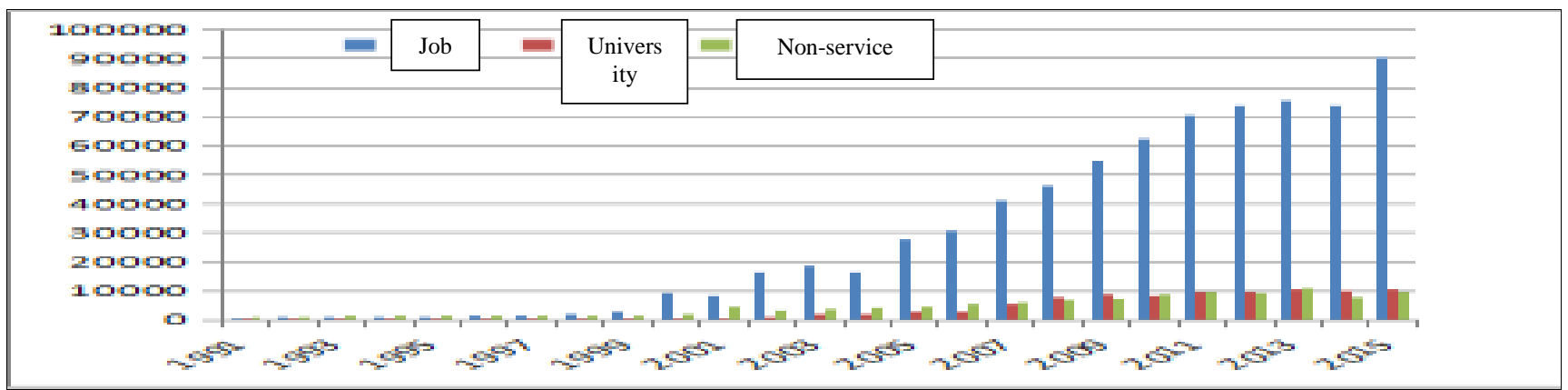

Fig. 1. Situation of patent applications in Shanghai from 1991 to 2015 (On-job and non-service invention status).

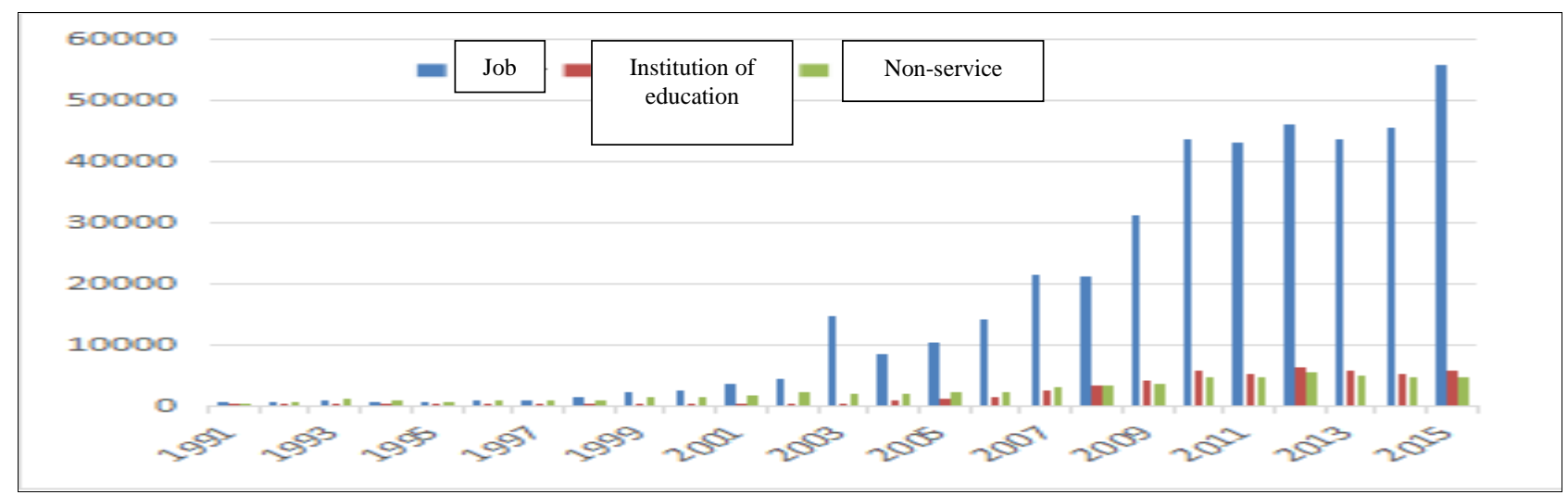

Fig. 2. Situation of patent applications in Shanghai from 1991 to 2016 (On-job and non-service invention status).

\section{Problems Faced by Colleges and Universities in the Protection of Intellectual Property}

It is a difficult, complicated and urgent task to increase the protection of intellectual property rights. Colleges and universities are the birthplace of knowledge-intensive, talented people, and invention-creation. It has a large amount of intangible assets involved, which can easily lead to the loss of intangible assets. The protection of intellectual property rights in universities involves almost every field. Coupled with the diversity of its forms, the flow of personnel, scientific and technological exchanges and cooperation, etc., it can greatly increase the difficulty of protecting intellectual property in colleges and universities. At the same time, the current technology management is not standardized. Awareness of intellectual property protection is not strong. And it would lead to serious loss of intellectual property rights. And infringement cases of intellectual property rights have occurred from time to time. All these have greatly increased the complexity of intellectual property protection in universities. In recent years, colleges and universities have made great achievements in the protection of intellectual property rights. It is also necessary to soberly realize that the recognition of intellectual property rights and practical work are far from meeting the needs of the development of domestic and international situations. And they must be accelerated. The protection of intellectual property in universities must overcome many difficulties and problems. These difficulties and problems must be studied and resolved in practice.

1) Intellectual property protection awareness: Due to the special nature of intellectual property rights, there must have special methods and means for its protection. Colleges and universities often lack the intellectual property protection awareness, confidentiality awareness, and legal relief awareness. It would result in the loss of their own intellectual property rights. In the context of the issuance of the "National Intellectual Property Outline" and the country's vigorous implementation of the patent policy, the scientific awareness of scientific research personnel in 
universities has greatly improved. However, it doesn't pay enough attention to patents. And the awareness is not high [4].

2) Management system: At present, the management of intellectual property in most colleges and universities has not yet deviated from the original administrative model. And the various aspects of intellectual property management have been disconnected. There is a lack of organic links. The management of intellectual property in many colleges and universities is still in a state of indifference [5].

3) Transformation of achievements: The technical achievements under China's long-term planned economy system are free to use. There have been many problems in the conversion of achievements in the recent years. At the same time, the university's index evaluation system has focused on papers and despised the intellectual property. Also, they have valued the achievements and despised the transformation. It has affected the transformation of scientific and technological achievements in universities into direct productivity. It has also led to the serious loss of school technical assets in the form of free or low-cost products [6] [7].

4) Personnel changes: The mobility of scientific research personnel in colleges and universities is high. Researchers have more part-time jobs. They send a large number of undergraduates, postgraduates, doctoral students and advanced students every year. It has increased the opportunities and channels for the loss of intangible assets in colleges and universities [8].

\section{COUNTERMEASURES AND ANALYSIS}

\section{A. To Strengthen the Concept of Property and Establish Intellectual Property Strategy}

1) To improve the recognition of intellectual property protection in colleges and universities: In recent years, the number of university patent applications in China has continued to grow rapidly. From the current number of public announcements (by the data in July 2017), the number of university applications in Shanghai have exceeded 10,000 since 2013. The number of patent applications (job inventions) was 10,595, a slight increase over 10,378 in 2015. The number of patents granted was also steadily increasing (Fig. 2). In 2016, 5,944 were authorized, up from 5,840 in 2015. This shows that the intellectual property awareness of universities and technologists has been significantly enhanced. However, it must be noted that the reason why universities attach importance to intellectual property rights is often due to the requirements of the competent authorities and comparison behavior of inter-college patent number. The scientific and technological personnel have filed patent applications. The patents, publication of papers and the identification of achievements become an important value indicator for promotion and appointment. This intellectual property awareness created by policy orientation or institutional strengthening not only lacks the internal drive and fundamental maintenance of the market interest mechanism, but also seriously misinterprets the legal connotation and social significance of the intellectual property system [7]. In fact, the intellectual property system is based on legal procedures and conditions to grant intellectual achievements to people who have a certain amount of exclusive rights over a certain period of time. And legal protection of this right is not violation of the legal system. It is not only an important legal system for protecting the achievements of intellectual labor under the conditions of market economy, but also plays an important role in encouraging economic innovation, regulating competition, and adjusting interests in economic and social development and scientific and technological progress.

2) To translate the protection of intellectual property through the whole process of scientific research management in universities: The protection of intellectual property rights should always run through the entire process of scientific research management in universities. First of all, in order to avoid the occurrence of low-level repetitive research or all kinds of intentional and unintentional infringement, patent search should be done well before the project being set up. During the research process, the new conception, new invention and new creation can apply for patent protection after the conclusion of the subject. It is necessary to do a good job of technical confidentiality for the achievements of "technical secrets". These "technical secrets" have not been patented. They don't taken part in exhibitions at home and abroad. The related content of technical secrets isn't published. It should protect the rights and interests of schools through special techniques and improve their competitiveness. During the validity period of the patent, the patented technology shall be transferred. And the market shall be exclusively protected by law. It is subject to the conditions of open technology. We should strictly control foreign technical cooperation, strictly abide the contract review system, and sign a legal, effective and detailed technical contract. The talent transfer, talent retirement, talent resignation and other ways would cause technology loss. Through the signing way, they should assume the duty of technical confidentiality such as non-use and non-confidentiality. Also, it should specify the corresponding economic responsibilities.

\section{B. To Improve the Organizational System and Strengthen the Protection of Intellectual Property}

At present, the management of intellectual property in universities and colleges in China usually belongs to the functions of the Science and Technology Department. Some universities also set patent offices and similar institutions. In fact, the management of intellectual property far exceeds the business scope of scientific research management. It cannot simply be a part of scientific research management. The intellectual property management belonging to the science 
and technology department is often limited to the level of results management. It lacks overall consideration to the upper, middle and lower reaches. The organization mode of patent office often stays in the application of patent. And it is difficult to manage the intellectual property in the whole process. With the restructuring and revocation of patent offices in colleges and universities, the protection of intellectual property rights has also been affected.

At present, domestic universities have begun to explore the establishment of a new intellectual property management organization model. As a functional department for the protection and management of intellectual property in schools, a special protection and management center for intellectual property rights in universities or research centers for the protection of intellectual property in special areas can be set up. This not only strengthens the management of intellectual property protection in schools, but also facilitates coordination with the Science and Technology Department and the Industry Department. The relationship among the relevant functional departments can also maintain and highlight the advantages of the school's distinctive fields. The system has greater flexibility and adaptability. It is adapted to colleges with intellectual property business.

The mode of setting up institutions of intellectual property protection in colleges and universities is the same as that of other institutions of management in colleges and universities. In order to strengthen the management of intellectual property rights and protect the legitimate rights and interests of colleges and universities, it is necessary to select schools at all levels according to their nature, tasks, directions of development, and the amount of intellectual property business. And it should meet the necessary and scientific principles. It would give full play to their managerial efficiency and achieve the purpose of strengthening the management of intellectual property rights and protecting the legitimate rights and interests of colleges and universities.

\section{To Formulate Rules and Regulations for Intellectual Property Protection in Universities}

In accordance with the requirements of the Regulations on the Administration of Intellectual Property Protection in Colleges and Universities promulgated by the Ministry of Education on 8 April 1999, Intellectual Property Management Measures or Patent Management Systems of Colleges and Universities in Shanghai have also emerged. And they are gradually improved. Almost all colleges and universities have established their own independent patent management system. Some have been included in the special intellectual property rights management system of schools. According to their own school characteristics, "patent license and technology development, transfer of the management policy are same". The patent implementation license of some colleges and universities has special management and funds policy than technology development and transfer.

Shanghai Ocean University issued the "Patent Management Measures of Shanghai Fisheries University" in July 2003. The Measures for the Administration of
Intellectual Property Rights of Shanghai Ocean University were revised and promulgated in December 2010. It defines the tasks of intellectual property protection in schools and the duties of colleges and universities in intellectual property protection. It also defines the duties of scientific researchers in intellectual property protection. At the same time, it also stipulates the incentive and support policies for intellectual property. It should establish a working system led by the headmaster. And the deputy headmaster should charge of it. And the Science and Technology Department and related colleges should be responsible for the management of intellectual property rights such as management, registration, review, rewards, punishments, and other specific issues. And then, it would protect the economic rights of school technicians and improve the enthusiasm of the protection of intellectual property rights of all employees. It would actively protect intellectual property rights.

\section{To Develop Property-rights Running to Promote the Transformation of Scientific and Technological Achievements}

The core of the connotation of intellectual property value is property rights. Knowledge as an asset can only reflect and obtain its value through legal operations. Therefore, the rich intellectual resources and the use of scientific and technological achievements in institutions of higher learning are indispensable conditions for the knowledge economy. This does not mean that the scientific and technological achievements of institutions of higher learning can naturally be transformed into industrial fields [9]. The key to intellectual property management is to transform technological advantages into economic benefits. It should fully tap scientific research projects with industrialized prospects, stimulate the enthusiasm of teachers and students in science and technology entrepreneurship, and gradually establish an institutional system conducive to innovation and entrepreneurship in schools.

As far as the general situation of our colleges and universities is concerned, the state has introduced a series of policies such as the Action Plan for the Further Implementation of the National Intellectual Property Strategy (2014-2020), Law of the People's Republic of China on Promotion of the Transformation of Scientific and Technological Achievements, "Provisions on Implementing the Law of the People's Republic of China on Promoting the Transformation of Scientific and Technological Achievements". Shanghai has also promulgated a series of encouraging policies, such as the Shanghai Municipal Action Plan to Promote Transformation of Scientific and Technological Achievements 2017-2020. Serial progress has been made in the transformation of scientific and technological achievements in colleges. Various colleges and universities have promulgated corresponding policies and systems for the transformation of scientific and technological achievements. Some colleges and universities have also set up specialized technology transfer companies. They specially promote the transformation of scientific and technological achievements in colleges and universities. However, the transformation of scientific and technological achievements 
has not met expectations. At the same time, the policy and system still need to be perfected in the aspects of operability and incentive measures. However, some colleges and universities have already found a successful way to transform scientific and technological achievements. And they have made remarkable achievements in the aspect of the combination of production, study and research.

The research work of Shanghai Ocean University has always been oriented to the countryside and the life of the people. With the unremitting efforts of scientific and technological workers in Shanghai Ocean University, the work has achieved fruitful results. And it has been fully affirmed by the society. In the nineties of last century, the school and Kingsoft Caojing Shrimp Aquaculture Company jointly set up "Shanghai Shencao Special Aquatic Product Development Company". It is the base of production, learning and research. Its goal is to explore how education serves production, how enterprises support education, and how to integrate education, scientific research and production. And then, it would achieve double harvests of teaching and production. The mode of the integration of production, learning and research has created the opportunity for schools to carry out teaching in the first line of aquaculture. Students have reached the first line of production and come into contact with the new trend of current production and the application of new results. They have learned the knowledge what they couldn't learn from books. Through the production practice, the content of students' learning is closely integrated with the teacher's scientific research. The teacher's scientific research achievements are reflected in teaching and applied to production in time. And the teaching quality and effect have been improved obviously. Through this kind of practice and exercise, students would apply, further enrich and improve the knowledge they have learned in the production. And they would enhance their hands-on ability and ability to find, think and solve problems. Industry-university-research cooperation education promotes scientific and technological progress of enterprises. At the same time, it would also promote the development of production. The company's fixed assets have grown from 20,000 yuan at its inception to 25 million yuan at present. It has been approved as the Shanghai Special Aquatic Seed Cultivation Center. It was also selected as Shanghai Penaeus Breeding Center and so on. It would engage in marine freshwater shrimp breeding and seedling breeding of marine freshwater shrimp and crab. The seedling has been exported to Guangdong and Hebei provinces. And the technology of seedling cultivation and cultivation of Marsh shrimp enjoys a certain prestige in Shanghai, Jiangsu and Zhejiang provinces.

\section{E. Publicity and Education of Intellectual Property and Other Work Related to Intellectual Property}

To enhance the concept of intellectual property rights is an important function of the intellectual property management institutions of universities, which is determined by the nature of modern higher education [10]. While grasping publicity and education, it is necessary to timely summarize and exchange experiences in the management of intellectual property rights, study the theoretical and practical issues related to intellectual property, improve the quality, and do a good job of management.

\section{CONCLUSION}

With the development of digital technology and network technology, the innovation, dissemination and diffusion of knowledge have been paperless, borderless and high-speed. The world economy is also changing from industrial economy to knowledge economy. And the development of human society has entered a rapidly changing era of knowledge economy. In the 70 years since the founding of China, especially in the 30 years since the reform and opening up, great progress has been made in science and technology undertakings. And the innovation ability of China has been greatly improved. A batch of major scientific and technological achievements of colleges and universities has exerted a great influence on the world. At the same time, many major scientific and technological problems have been solved for the economic construction and social development of China. While affirming our achievements, we should also soberly realize that the competition in today's world is ultimately a competition of economic strength and a competition of scientific and technological innovation capabilities. The gap between China's technological innovation capacity and the needs of national development is different from the international advanced level. Compared with foreign universities, the conversion rate of intellectual property in domestic colleges and universities is generally low. And the proportion of high-quality intellectual property is relatively small. Colleges and universities should undertake more tasks of scientific and technological innovation. This is especially true for featured universities. Therefore, China should establish and perfect the innovation system and mechanism as soon as possible, give full play to the "late-developing advantage", learn from the experience of advanced countries, and make great efforts to establish the intellectual property protection system with the characteristics of Chinese colleges and universities.

\section{REFERENCES}

[1] $\mathrm{Hu}$ Rongchun. Management status and countermeasures of intellectual property in colleges and universities [J]. Digest of Management Science, 2014, (24):121-123. 胡荣春. 高校知识产权的 管理现状及对策[J].管理观察,2014,(24):121-123

[2] Tang Ying, Fang Liang, $\mathrm{Xu} \mathrm{Xu}$, et al. Problems and suggestions on intellectual property management in colleges and universities [J]. Scitech \& Development of Enterprise, 2015, (12):105-106. 唐莹,方亮,徐 旭等.高校知识产权管理存在的问题及建议 [J]. 企业科技与发展, 2015,(12):105-106

[3] Annual Report on Patent Statistics of State Intellectual Property Office 1985-2016 [EB/OL]. http://www.sipo.gov.cn/tjxx/,2017-0630/2017-08-13. 国家知识产权局专利统计年报 1985-2016[EB/OL]. http://www.sipo.gov.cn/tjxx/,2017-06-30/2017-08-13

[4] Wei Jipeng. Discussion on patent management in colleges and universities under the background of building an innovative country [J].China Invention \& Patent, 2016, (12):14-16. 韦记朋.创新型国家 建设背景下高校专利管理工作探讨 [J]. 中国发明与专 利,2016,(12):14-16

[5] Zhou Shuling, Zhang Yingyan, Qi Guanbin. Practice and thinking on the management of intellectual property in local colleges and 
universities - A survey of data from SZ Academy of Anhui province [J]. Yinshan Academic Journal, 2017, 31 (3):141-144. 周书灵,张英 彦, 齐观涁. 地方高校知识产权的管理实践与思考一来自于安徽省 SZ 学院的数据调查[J].阴山学刊,2017, 31 (3):141-144

[6] Ji Chun. To improve the innovation capability of intellectual property of local agricultural universities [J]. Management for Economy in Agricultural Scientific Research, 2017, (2):33-36. 姬春.提升地方农 业高校知识产权创新能力[J].农业科研经济管理,2017,(2):33-36

[7] Chen Min. Problems in the management of intellectual property in local universities and their solutions [J].Citizens and Law, 2016, (8):50-53. 陈敏. 地方院校知识产权管理存在问题及解决思路 [J]. 公 民与法,2016,(8):50-53

[8] Yin Xiaobing. Analysis on the state of intellectual property in colleges and universities during the transitional period and its development countermeasures $[\mathrm{J}]$. Innovation Science and Technology, 2016, (4):18-21. 尹晓兵. 转型期高校知识产权状况剖 析与发展对策研究[J]. 创新科技,2016,(4):18-21

[9] Wang Ying. On the protection of intellectual property in the transformation of scientific and technological achievements of university [J]. The Science Education Article Collects, 2017, (402):13. 王芗. 浅议高校科技成果转化中的知识产权保护问题 [J]. 科教文 汇,2017,(402):1-3

[10] Wei Xiaofeng. Study on the protection of intellectual property in universities [M]. Liaoning: Liaoning Normal University. 魏晓峰.高 校知识产权保护问题研究 $[\mathrm{M}]$. 辽宁:辽宁师范大学. 